\title{
Examining Determinants of Turkey Export to OIC Member Countries
}

\author{
Arab Dahir Hassan \\ E-mail: arab.hassan@ogr.sakarya.edu.tr
}

\begin{abstract}
Using the traditional gravity model, this paper aims to analyze the determinants of Turkish exports to 41 OIC (Organization of Islamic cooperation) countries for the period from 2000 to 2017. Specifically, the paper analyzed the historical links, humanitarian diplomacy, economic diplomacy, trade costs and economic sizes as the main explanatory factors of the export of Turkey to Islamic countries. After implementing various robustness checks, results indicate that the economic size of OIC member countries and Turkish official development assistance have statistically significant effect on Turkish volume of export to OIC, however the GDP of Turkey was negative but not significant, which is contrary to the general assumption of Gravity model. The other factors such as common language, trade agreements, and Turkish business consulates are also found positive impacts on export of Turkey to OIC but not statistically significant.
\end{abstract}

Key words Gravity model, volume of export, OIC

DOI: $10.7176 / \mathrm{JSTR} / 5-2-18$

\section{Introduction}

The Organization of Islamic Conference (OIC) was first established on 25th September 1969 in response to the occupation of Jerusalem (Palestine). It goes without saying that the organization was established for political reasons to support the struggle of occupied Palestinian in Palestine. Although the organization failed to solve its targeted goal to put an end the occupation of Israel in Palestine, this did not lead termination of the organization and not to expand its scope of objectives. To expand the scope and degree of cooperation among the Muslim Nations, OIC formulated policies intended to boost economic and trade relationship among the member countries. For example, the establishment of Islamic Development Bank (IDB) in 1975 following the Conference of Finance Ministers of Muslim Countries in 1973 was intended to promote economic cooperation among OIC member countries. The bank has been accredited in several research papers that it played effective role in promoting intra-trade and intrainvestment among the OIC countries. Following the initiative shift of the organization from political ineffectiveness to more economic cooperation, sub-regional trade blocks emerged within the OIC countries; Gulf Cooperation Council (GCC), the Arab Maghreb Union (AMU), the Council of Arab Economic Unity (CAEU), the Economic Cooperation Organization (ECO) and there was also suggestion related to implementation of common Islamic market.

The organization of Islamic Cooperation (OIC) is the second largest intergovernmental organization after United Nations with a membership of 57 nations dwell in all four continents. According to World Bank data, the population of the 57 states and territories was around 1.769 billion in 2016, which is 23.77 percent of the world's people, The Organization of Islamic Cooperation (OIC) contributed around \$6.425 trillion to the world's gross domestic product (GDP) in 2016, this is equivalent to 8.51 percent of the world's GDP. One feasible reason for this could be 20 -member countries of OIC are in the list of least developing countries for long as the United Nation's department of Economic and Social affairs published in 2018. There huge and diverse of debates about why Muslim countries left behind, prolonged conflicts, absence of good governance, backwardness of science and technology have been repeatedly underlined in different studies as the main explanatory factors of the issue. Although OIC member countries have low economic prestige, but they endowed or possess most world economic drivers such gas and energy reserves. They also have extreme geographical significance for the follow of world's water borne trade since world's most trades routes- strait of Mallaca, strait of Hormuz, Suez Canal, and Gulf of Aden- are under the geographical territories of the OIC member countries. 
Turkey is a developing and emerging political power and has been leading the leadership of OIC Organization for the last terms. Turkey shares several important denominators - cultural links and common historical and religious identity- with Muslim countries. Turkey maintained trade surplus over trade with OIC as the import and export indexes show, the rate of export mounted from $12 \%$ in 2000 to $28 \%$ in 2017 while imports changed from $11 \%$ to $13 \%$ in this period. This study strives to examine empirically factors that effect Turkey's volume of export to OIC countries.

The structure of the study was organized as following; the first section of the study gives brief introductory about Organization of Islamic Cooperation (OIC), the second section reveals literature review and how research gap was identified, and the third section shows methodology and model specification. Fourth section gives snapshot about Turkey-OIC intra-trade developments, and the section displays empirical findings and the conclusions drawn.

\section{Theoretical Frame Work}

The gravity model has been widely used in empirical studies of international trade since the early sixties to explain bilateral trade between countries. Tinbergen (1962) and Poyhonen (1963 were the pioneers of gravity model application international trade; they used to explain bilateral trade among European countries. The original idea of the gravity model directly linked bilateral trade volume to the size of the economies, and inversely related to geographical distance which is proxy of transportation and communication costs. However, the scope of the gravity model has been widened in recent studies by adding any factors that can have an impact on trade follow among countries. For example, Noh \& Heshmati (2017) employed gravity model to analyze weather official development assistance effect donor's export. Head \& Ries, and Girma \&Yu $(998 ; 2002)$ investigated linkage between immigration and trade using gravity model. Since gravity model has been pioneering in studding bilateral trade follows among countries, most of the studies conducted on intra-trade among Islamic countries have been employed gravity model approach as we will see in the concise literature review in the bellow section.

Ghani (2007) employed gravity model to analyze the effects of being a member of OIC on trade with OIC member countries and non-OIC countries. The results of this study showed that when traditional gravity model is applied the OIC membership has negative effects on trade, while theoretical gravity estimates indicated positive effects or non-significant. However, Abidin, Bakar, \& Sahlan, (2013) and Gundogdu (2009) endeavored to reveal what determined intra-OIC imports increased 14.4 to $17.6 \%$ 2002 and 2006, by analyzing tariff, trade facilitation and liberalization \& depreciation of exchange rate, his findings highlighted that OIC member countries started trade each other and the rest of the world following Makkah declaration and ten-year program of action to increase intra-OIC trade 20 percent of global trade in 2015. Although trade liberalization implemented by OIC member countries improved GDP per capita growth in the short term, but it did not improve imports, exports and total trade of the members (Ghani, 2011)

The export of Malaysia to OIC countries is positively associated with GDP and negatively proportional to GDP per capita and real exchange rate (Abidin et al, 2013). This is also consistent with the result of cross-sectional analysis of intra-OIC trade conducted by Bendjilali (2000). Bendjilali's study outlined that intra-OIC trade members is positively affected by the size of their economies, the extent of Islamic Bank (IDB) trade financing, and their co-membership in the regional integration schemes.

Abidin \& Haseeb (2018) also examined the impact of macroeconomic indicators and Islamic financial indicator on Malaysia-Gulf cooperation bilateral trade. The result of their paper indicated that real exchange rate, inflation and distance are negatively affected bilateral trade between Malaysia and GCC countries, while GDP, No. of Islamic banks and Zakah collection are positively associated with MalaysiaGCC bilateral trade. GCC is unique sub-regional organization of OIC, due to its endowment of energy, open trade regimes and dependency on entirely export of oil and gas and imports of consumer goods, GCC dominates intra-OIC trade (Insel \& Tekce, 2003).

Khalifah (1993) investigated the structure of intra-Muslim countries trade and revealed that the trade contributions of the high-income Muslim countries are greater than the lower and upper middle-income countries. Her recommendations underlined that any form of trade integration among the Muslim countries must incorporate countries especially from the Middle East. Yousuf \& Al-Atrash (2000) using gravity model investigated weather trade between Arab countries is low or not, their findings revealed that Arab countries trade less than as the gravity model predicted. This paper shed on light that Arab countries have several common denominators such as common religion, common language and culture, 


\author{
Vol $, \mathrm{No} 2,2019$
}

but there are political disputes and high level of trade protectionism, which makes intra-Arab trade volume absolutely and relatively very small than it is supposed to be. Contrary to this Boughanmi (2008) investigated the potential of trade of the GCC countries within the context of the old and the emerging preference trade arrangements in the region of Middle East and North African Countries (MENA). The findings of the study show that GCC countries essentially trade more with each other than as the gravity model predicted.

There are limited number studies inclined to investigate the impact of institutional capacity on intra-OIC trade. Yogatama \& Hastiadi (2015) examined the role of democracy and governance in promoting Indonesian export to OIC member countries using gravity model. The results presented that both democracy and governance in Indonesia have positive and significant effect in enhancing Indonesian exports to the OIC countries. on the other hand, Bilgin et al (2017) analyzed the impact of 12 political risk measures(bureaucracy quality, corruption, democratic accountability, government stability, internal and external conflict, investment profile, law and order, military in politics, religious and ethnic tensions, and socioeconomic conditions) in the Islamic countries on the volume of Turkey export. The empirical findings of the gravity model indicated that the government instability in the importing countries is negatively associated with the volume of exports of Turkey. 


\begin{tabular}{|c|c|c|c|c|}
\hline Author(s) & Study description & $\begin{array}{c}\text { Sample } \\
\text { period }\end{array}$ & Methodology & Findings \\
\hline $\begin{array}{l}\text { Khalifah } \\
\text { (1993) }\end{array}$ & $\begin{array}{l}\text { This paper examines } \\
\text { trade structure of } 50 \text { of } \\
\text { Muslim countries. }\end{array}$ & $\begin{array}{l}1986- \\
1991\end{array}$ & $\begin{array}{c}\text { Trade intensity } \\
\text { index }\end{array}$ & $\begin{array}{l}\text { The Muslim countries in the middle } \\
\text { east and Turkey possesses dominates } \\
\text { trade with in Muslim countries and the } \\
\text { rest of the world. }\end{array}$ \\
\hline $\begin{array}{c}\text { Bendjilali } \\
(2000)\end{array}$ & $\begin{array}{l}\text { This is econometric } \\
\text { analysis of intra-OIC } \\
\text { trade. }\end{array}$ & 1994 & Gravity model & $\begin{array}{l}\text { The study revealed that intra-OIC trade } \\
\text { is positively affected by size of their } \\
\text { economies, extent of trade finance, and } \\
\text { regional integration, and negatively } \\
\text { affected by transportation and } \\
\text { communication cost. }\end{array}$ \\
\hline $\begin{array}{l}\text { Yousuf \& } \\
\text { Al-Atrash } \\
(2000)\end{array}$ & $\begin{array}{l}\text { This study endeavors to } \\
\text { examine weather trade } \\
\text { between Arab countries is } \\
\text { low or not. }\end{array}$ & $\begin{array}{l}1995- \\
1997\end{array}$ & Gravity model & $\begin{array}{c}\text { The results indicated that Arab } \\
\text { countries trade less with each other and } \\
\text { the rest of the world. }\end{array}$ \\
\hline $\begin{array}{l}\text { Ghani } \\
\text { (2007) }\end{array}$ & $\begin{array}{l}\text { This study examined how } \\
\text { being a member of OIC } \\
\text { effects trade with OIC \& } \\
\text { the rest of the world. }\end{array}$ & $\begin{array}{l}1997- \\
2002\end{array}$ & Gravity model & $\begin{array}{l}\text { The traditional gravity model shows } \\
\text { the effects of OIC membership are } \\
\text { negative, but theoretical gravity model } \\
\text { show negative or non-significant. }\end{array}$ \\
\hline $\begin{array}{l}\text { Gundogdu } \\
\text { (2009) }\end{array}$ & $\begin{array}{l}\text { The study investigated } \\
\text { the determinants of OIC } \\
\text { intra-trade. }\end{array}$ & $\begin{array}{l}1995- \\
2007\end{array}$ & Gravity model & $\begin{array}{l}\text { Findings underlined that OIC member } \\
\text { counties started to trade each other } \\
\text { with the help of liberalization. }\end{array}$ \\
\hline $\begin{array}{l}\text { Ghani } \\
\text { (2011) }\end{array}$ & $\begin{array}{l}\text { This paper scrutinizes the } \\
\text { effect of trade } \\
\text { liberalization on imports, } \\
\text { exports and GDP per } \\
\text { capita of Organization of } \\
\text { the Islamic Conference } \\
\text { (OIC) member countries. }\end{array}$ & $\begin{array}{l}1970- \\
2004\end{array}$ & $\begin{array}{c}\text { Regression } \\
\text { analysis }\end{array}$ & $\begin{array}{l}\text { The shows that liberalization process } \\
\text { in the OIC countries improved short } \\
\text { run growth of the member countries } \\
\text { but not improved imports \& export. }\end{array}$ \\
\hline $\begin{array}{l}\text { Abidin et } \\
\text { al,( 2013) }\end{array}$ & $\begin{array}{c}\text { The papers aims to } \\
\text { examine factors effect } \\
\text { Malaysian export to OIC } \\
\text { countries. }\end{array}$ & $\begin{array}{l}1997- \\
2009\end{array}$ & Gravity model & $\begin{array}{l}\text { The study highlighted that Malaysian } \\
\text { export to OIC counties is determined } \\
\text { by size of the economy, exchange rate, } \\
\text { and level of openness. }\end{array}$ \\
\hline $\begin{array}{l}\text { Boughanmi } \\
\text { (2008) }\end{array}$ & $\begin{array}{l}\text { This paper is to examine } \\
\text { the potential of trade of } \\
\text { the GCC countries within } \\
\text { the context of the old and } \\
\text { the emerging preference } \\
\text { trade arrangements in the } \\
\text { region of Middle East and } \\
\text { North African Country. }\end{array}$ & $\begin{array}{l}1993- \\
2004\end{array}$ & Gravity model & $\begin{array}{l}\text { The results show that though fact that } \\
\text { the share of GCC intra-trade is too } \\
\text { small in absolute terms, it is actually } \\
\text { higher than it is expected. }\end{array}$ \\
\hline $\begin{array}{l}\text { Yogatama \& } \\
\text { Hastiadi } \\
(2015)\end{array}$ & $\begin{array}{l}\text { This study explores the } \\
\text { role of democracy and } \\
\text { governance in the } \\
\text { promotion of Indonesian } \\
\text { exports to OIC countries. }\end{array}$ & $\begin{array}{l}1998- \\
2012\end{array}$ & Gravity model & $\begin{array}{c}\text { The study indicated that both } \\
\text { democracy and governance have a } \\
\text { positive effect in enhancing Indonesian } \\
\text { export. }\end{array}$ \\
\hline $\begin{array}{c}\text { Bilgin et al ( } \\
\text { 2017) }\end{array}$ & $\begin{array}{c}\text { This study examines } \\
\text { determinants of export of } \\
\text { Turkey to OIC countries; } \\
\text { specially this study } \\
\text { emphasis political risks. }\end{array}$ & $\begin{array}{l}1996- \\
2015\end{array}$ & $\begin{array}{l}\text { Gravity } \\
\text { approach }\end{array}$ & $\begin{array}{l}\text { The paper discoveries that the } \\
\text { government instability in the Islamic } \\
\text { countries is negatively associated with } \\
\text { the Turkish exports. }\end{array}$ \\
\hline
\end{tabular}


The above elaborated literature review about intra-trade among Islamic cooperation organization (OIC) members shows two main important points; gravity model has been extensively applied studies related to intra-OIC trade, and most importantly there is only one study covering intra-trade between Turkey and OIC countries in our knowledge. Therefore, our study using multivariate analysis covering all possible variables that effect trade between Turkey \& OIC countries intends to contribute this shortage of literature.

\section{Methodology and Empirical Analysis Theoretical development and model identification}

The gravity model is one of the applied international trade models that have been widely used in literature of international economics. Thousands of scientific research papers covering different aspects of trade have been published using gravity model. Tinbergen in1962 developed gravity model intuitionally but lacked theoretical foundation. However, it was recognized as one of the most successful models in economics (Anderson \& Van Wincoop, 2003, 170). The gravity model is an empirical model that endeavors to deeply understand and explain factors effect trade flows between countries, and it was literally proved that gravity model is the most suited tool that can be used to explain determinants of export of a country to its trade partners (Irandu, 2018). Most of the classic international trade theories are emphasized to understand qualitatively; which countries a certain country can trade and what goods? However, gravity model attempted to answer an equal important quantitative question of how much a certain country trades with its trade partners and what determines?

Gravity model is a successful econometric model that aims to comprehend in depth factors determining trade flows between country $i$ and its trade partner county j. Enormous number of gravity model papers are published to analyze and reveal the impact of trade policies on bilateral between countries. Some of the trade policies tremendously studied and displayed in the literature of international trade empirics include; the effects of trade openness, protectionism, national borders, and the role of regional trade agreements (Sohn, 2005). The empirical analysis of gravity model was also covered and heavily analyzed other types of flows rather than trade goods such migration, commuting, and tourism $(\mathrm{H}$. Bergstrand, 1985). Kimura \& Lee (2006) the gravity model-based studies will no longer limited analyzing trade in goods, but also gravity model covers trade in services due to its robust and consistent empirical results.

Gravity model is popular and impressive model because it is analogous to the equation of gravity theory in Newtonian Physics. Newton's gravitational law is based on two main assumptions; the gravitational force between objects is directly related to the masses of objects and inversely related to the distance between objects. The standard gravitational model is expressed mathematically;

gravitational force $=\frac{(\text { gravitational constant })(\text { mass of object } 1)(\text { mass of object } 2)}{(\text { distance between objects })^{2}}$

This formula implies that the gravitational force of attraction directly proportional to the masses of objects massive objects attract each other with greater force of attraction; while gravitational force of attraction indirectly proportional to the square of distance between objects distant objects attract each other with weak force of attraction.

Keeping in mind with this well-known physics wisdom, the same is true is applied on studding volume of trade between countries. Utilizing the Newtonian formula, the analogy formula for volume of trade between countries can be designed like this:

$\mathbf{X i j}=\mathbf{a}$ GDPi $\times$ GDPi /D

$\mathrm{Xij}=$ volume of trade between country $\mathrm{i}$ and country $\mathrm{j}$.

$\mathrm{a}=$ constant

GDPi $=$ gross domestic product of country $\mathrm{i}$

$\mathrm{GDP} j=$ gross domestic product of product of country $j$

$\mathrm{D}$ or in some models $\mathrm{T}=$ distance between country $\mathrm{i}$ and country $\mathrm{j}$ which is a proxy of trade costs.

150 | P a g e

www.iiste.org 
However, since the gravity model became the center of international trade studies due to its consistency empirical results, other standardized trade cost proxy variables have been heavily discussed in the literature. Some of these variables include adjacency, common language, colonial links, common currency, r co-membership in a political entity, island, landlocked, institutions, infrastructures, migration flows, tariff and other barriers (H. Egger \& Nigai, 2015; Ramos \& Surinach, 2016; Figueiredo , Lima \& Orefice, 2016 ).

The gravity model equation can be reshaped into a linear form to comply with the usual regression analysis as shown below:

Tradeij $=\alpha+\beta 1$ GDPi $+\beta 2$ GDPj $+\beta 3$ DISTij $+\mu \mathrm{ij}$.

The parameters such $\alpha, \beta, \mu$ are normally estimated in a log linear form of the model. The essential theory behind the gravity model is that great nations in economic size have plethora foreign trade volume between them. They also have the capability to attract large shares of other countries ' consumer preferences because of their variety of product categories and services. In addition to that the gravity model indicates that as distance increases, the volume of trade between any two countries shrinks other things being constant (Chaney, 2018).

\section{Model specification}

This study aims to examine determinants of volume of export of Turkey to its co-political institution and religious identity the organization of Islamic cooperation (OIC). To understand what most specifically determines the rate of export of Turkey to OIC member countries the study employs a gravity model which almost century is applying to study determinants of bilateral or volume of trade between countries ( Nguyen \& Vo, 2017).

The model of the study expressed as the following according to the traditional gravity model form;

LinTurkexport $=\beta 0+\beta 1$ linGDPturkey $+\beta 2$ LinGDPoic $+\beta 3 \ln D$ ISTturkOIC $+\beta 4$ LinODAturk $+\beta 5$ LinPoptr + $\beta 6$ LinOICPop $+7 \beta$ LinEconfreedomturk $+\beta 8$ LinEcofredomoic $+\beta 9$ LinBusineConsutr + $\beta 10$ LinCommonBordertroic $+\beta 1$ LinCommonLngtroic $+\beta 12$ LinTRDAGRMtroic .

Where;

1. Turkeyexport $=$ the export from Turkey to OIC member country in year $t$

2. GDPturkey : the size of GDP of turkey in year $\mathrm{t}$

3. GDP OIC: GDP of OIC country in year $t$

4. DISTturkOIC : The distance between Ankara and capital city of OIC country

5. ODAturk : The official development assistance from Turkey to OIC country in year $\mathrm{t}$

6. Poptr: Population of Turkey in year T

7. OICPop: Population of OIC countries in year $\mathrm{T}$

8. Ecofreedomturk: level of economic freedom of Turkey in year $\mathrm{T}$

9. EcofredomOIC : level of economic freedom of OIC countries

10. BusineConsultr: The business consulate of Turkey in OIC country (dummy variable).

11. CommonBordertroic : common border between Turkey and OIC country ( dummy variable)

12. CommonLngtroic: common language of Turkey and OIC country (dummy variable)

13. TRDAGRMtroic: Trade agreement between Turkey and OIC country (dummy variable)

The variables in the equation above can be grouped into three main categories. The first group such as GDP, distance and export represent the original variables of the gravity model. The variables positioned in the second part of the equation line including the amount of official development assistance Turkey donated to OIC co-member country, level of economic freedom of Turkey and OIC country, are the main explanotay variables. The variables in the last part of the equation are dummy variables include opening business consulates in OIC country, common border between Turkey and OIC country, similarities in language between Turkey and OIC, and trade agreements between Turkey and OIC country. 


\section{The development of Turkey - OIC Trade relations}

Turkey has a long -lasting historical ties - 600 years old history of Ottoman empire, with the Muslim countries. Although, after the collapse of Ottoman empire in 1919, the founder of Turkey Republic, Mustafa Kamel Ataturk, implemented critical reforms, which critics said it was distanced Turkey from the Muslim countries, and religion affiliated ruling system, the legacy of Ottoman empire as the heritage of Muslim-wide empire remains immortal. The first government of Turkey Republic and the followed governments were not inclined to strengthen multidimensional links with the countries lied under the Ottoman's authority and the rest of the Islamic states.

This was one of the reasons that could be explained why Turkey implemented silent and passive foreign policy for Muslim world related international issues, while economic incompetency and long-lasted political anarchism the republic experienced for decades were also among top listed reasons behind the Turkish foreign policy passiveness. However, in 1990 Turkey foreign policy has been made a comprehensive reform to adapt global dynamic political changes. For example, Turkey participated Gulf war (invasion of Iraq to Kuwait), supported Gulf states to defend Saddam Hussein from Kuwait, and gave platform American warplanes to strike Saddam's military bases. This indicates Turkey's foreign policy orientation changes (from passive to more insider style) about middle east crises and Turkey's position in the region here after.

Post-Cold War changes such as the Gulf War, the emergence of the Turkic republics in Central Asia \& Azerbaijan, and ethno-national conflicts in the Balkans have opened new opportunities window for Turkey to play active role in several regions to outshine international arena. This power of historical, cultural, and ethnical links gave Turkey new potential markets to its export-based economic development model (Sayari, 2000). The Turkish government Shifted the paradigm of its economy -from inward looking and protective style to more outward looking and liberal markets. The Turkish economy to integrate with world economy critical liberalization steps were taken including liberalizing foreign trade and then liberalizing financial and capital markets (Ucal \& Alıc1, 2003).

Turkey to achieve its desire as an emerging global power and implements import substitution and export promotion development strategies, innovative diplomatic channels were developed. For example, in 1992 Turkish coordination and development agency was established (TIKA) to create strong cooperative ties especially in the Turkic Republics, and any other regions where Turkey historically and culturally linked. TIKA implemented a very dramatic humanitarian aid diplomacy which created strong sympathy for Turkey in the Turkish foreign aid recipient countries, which are mainly members of OIC (Organization of Islamic Cooperation) and other OIC non-member Muslim countries. Another important step taken to boost Turkish volume of export and attract international investment was that establishment of foreign economic relations board (DEK) in 1986 and its restructure in 2014. This foreign economic relations organization implements country's economic diplomacy under the authority of the line ministry of foreign affairs. The tasks assigned to this organization include organizing and managing foreign economic relations of Turkish private sector, to assess investment opportunities at home and abroad to share with Turkish business communities. It has business consulates in many countries specifically in all OIC member countries to facilitate bilateral foreign trade and investment. 
Graph 1: Turkey export by group countries.

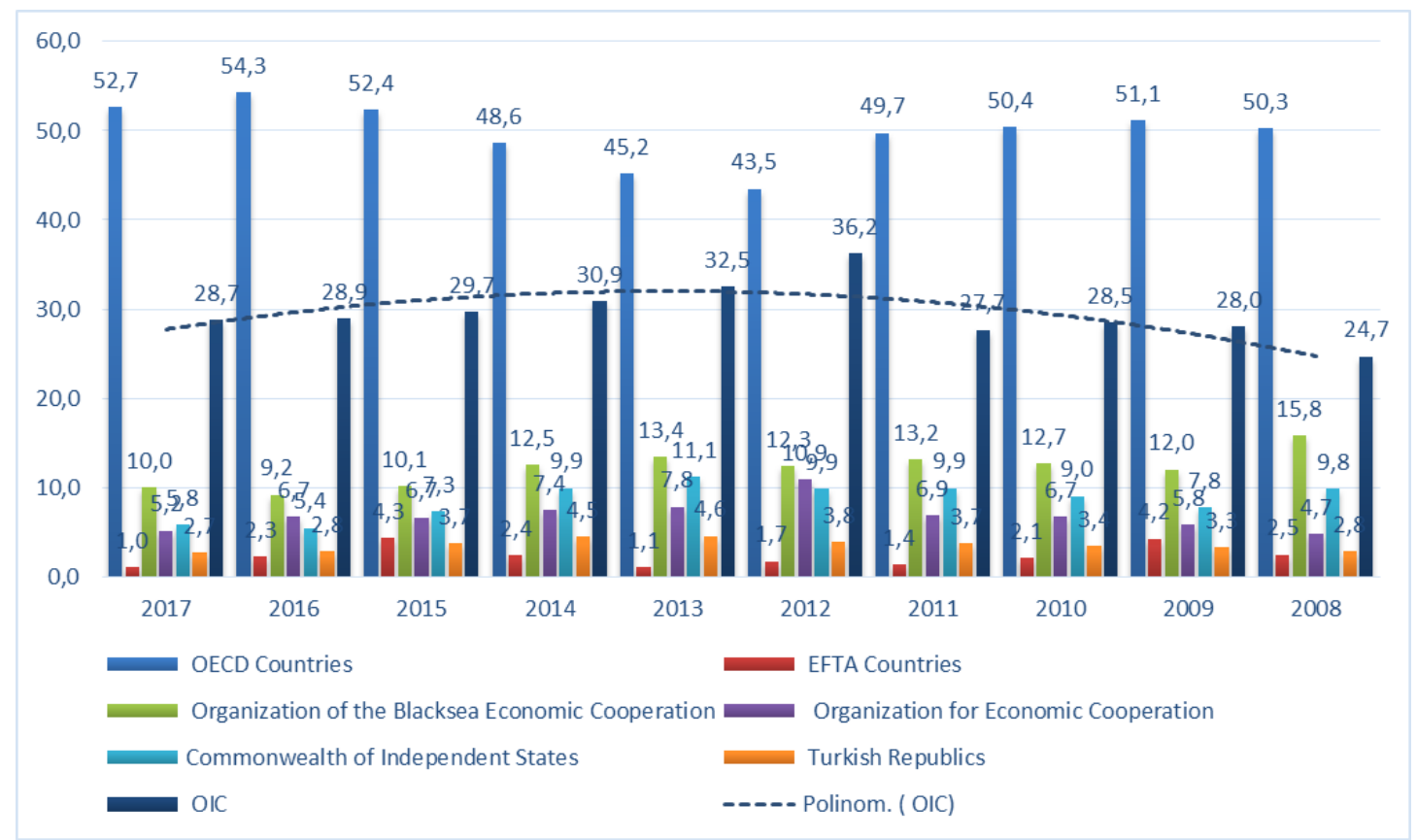

Source: Turkey Statistical Institute, 2008-2017

The above graph shows distribution of volume of Turkey export to country groups such as OECD, Organization for Economic Cooperation, Common Wealth independent States, Turkish Republics, Organization of the Black sea for Economic Cooperation, EFTA, and Organization Islamic Cooperation. The rate of export of Turkey to OECD 50.3\% in 2008 and $52.7 \%$ in 2017 which makes the most recipient of Turkish export. In contrast, Organization of Islamic Cooperation (OIC) which this study specifically examines also plays crucial role in Turkish export share. Turkey exported $24 \%$ in 2008 and $28.7 \%$ of its export to Islamic countries in 2017. This makes OIC the second largest intergovernmental organization that Turkey trades. What is also remarkable to put an emphasis is the rate of Turkish export volume to OIC has been increasing steadily in an average rate of $28 \%$, which signifies that OIC is significant and permanent trade partner of Turkey.

The intra-merchandise export and import between Turkey and Organization of Islamic Cooperation (OIC) member countries has gone through different ups and downs in last three decades. The volume of merchandise of Turkey export to OIC in 1985 was $41 \%$ while import was $33 \%$. This was the result of structural reforms in Turkish Economy, which led favorable economic growth and low inflation rate in the early 80s. However, due to successive decrease in GDP growth and increasing inflation rate in the end of 80s, Turkish export to OIC and import exponentially decreased, reached $19 \%$ and $17 \%$ respectively. This was "boom-bust" case as the Ertuğrul \& Selçuk (2001) argued. The liberalization commenced in the 1980s was not go together with sound macroeconomic policies or an adequate strengthening of the institutional and regulatory framework, that could cause the economy to remain healthy ( Macovei, 2009). Restructure of the economy and aftermath of 2001 severe economic crisis of Turkey also shows speedy of export growth to OIC and steadily growing import growth from Islamic countries. For instance, export increased $13 \%$ in 2001 to $28 \%$ in 2009, while imports maintained average growth rate of $13 \%$ from 2001 to 2009 .

153 | P a g e

www.iiste.org 


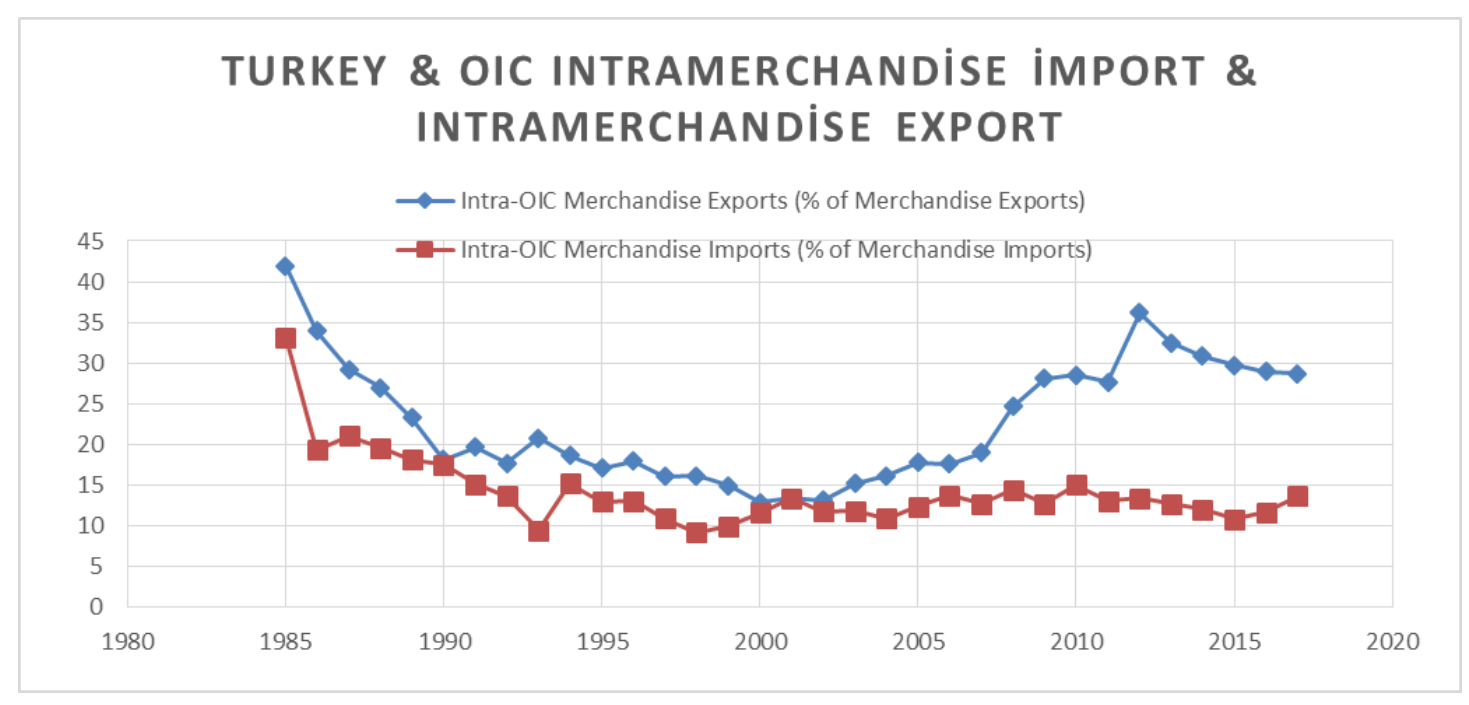

Source: SESRIC (data is sourced from SESRIC data base, but the author sketched the graph on his purpose), 1985-2017.

\section{Empirical findings}

Employing the fixed effect and random effect estimators gave all most similar results. The random effect is rarely used in the literature because of its weak features to address the gravity model while a fixed effect is frequently employed but it does not include some dummy variables as they are and thus difficult to test hypotheses in this type of extended gravity model with many dummy variables related to the major objective.

According the original structure of the gravity model, which consist of GDP size and distance, the study has employed the same structure. Increase of GDP in OIC countries significantly increases the export of Turkey to OIC countries, while increase of GDP in Turkey decreases export to OIC but significantly. At $5 \%$ level of significance, $1 \%$ change in GDP of OIC created $0.7 \%$ increase in export of Turkey to OIC, but $1 \%$ change in GDP of Turkey created $-0.3 \%$ decline of Turkey export to OIC, this is contradicting to the general rule of traditional Gravity model. On the other hand, the increase in distance reduces export volume by $-1.176 \%$, since distance is proxy of trade cost, as the costs increase export volume shrinks. The other section of the equation increase in population of Turkey creates $8 \%$ increase of volume of export but change population in OIC countries has less significant effect on export volume. Here population we used as a proxy of market size. Turkey economic openness has slightly effect of export of Turkey to Muslim countries, while level of Economic openness has negative and statistically significant impact on volume of export, $1 \%$ change in level of economic openness in OIC countries leads $-1 \%$ decline in volume of export of Turkey. Official development assistance proxy of humanitarian diplomacy of Turkey was found that it has statistically significant impact on volume of Turkey export to OIC. $1 \%$ change in ODA (official development assistance creates 0.05 increase in volume of export to OIC.

Other dummy variable such trade agreements, common language and business consulates was found positive relationship with volume of export but not statistically significant. Finally, common land border was found negative effects on Turkey export but statistically significant. 
Table 1: Estimation results

Random Effects Model

$\begin{array}{lc}\text { LOGGDPtrt } & -0.2864(0.52) \\ \text { LOGGDPOIC } & 0.7269(7.18)^{*} \\ \text { LOGdistance } & -1.176(-5.90)^{*} \\ \text { LOGPopulationtr } & 8.00(3.80)^{*} \\ \text { LOGOICPopulation } & -0.197(-1.52) \\ \text { LOGTurkeyeconfredom } & 0.461(1.27) \\ \text { LOGEcofredomOIC } & -1.00(-3.26)^{*} \\ \text { LOGODA } & 0.057(3.63)^{*} \\ \text { LOGTrdadeagrement } & 0.146(1.48) \\ \text { LOGComercon } & 0.149(1.65) \\ \text { LOGLandborder } & -.165(-0.48) \\ \text { Commonlang 0 } & 0.572(0.79)\end{array}$

Fixed Effects Model
$-0.403(-0.73)$

$1.244(6.42) *$

$5.79(2.61)^{*}$

$0.334(0.70)$

$0.40(1.11)$

$-0.656(-1.89)$

$0.0538(3.38)^{*}$

$0.142(1.33)$

$0.1422(1.50)$

$-0.6068(-1.24)$

\begin{tabular}{ll}
\hline Observations & 505 \\
R-Squared & 0.76 \\
F-test & 5.00
\end{tabular}

Note: $*=$ significant level at $5 \%, \mathrm{t}$-statistics is noted in parentheses.

\section{Conclusion}

Turkey has been adapting export promotion-oriented policies for the last decades, regions like OIC is one of the potential markets targeted. Being having several denominators (religion, culture and history) with Turkey makes this market unique. This empirical study found that size of OIC economy, official development assistance, trade agreements, commercial consulates; languages similarities have deterministic effect on the volume of export from Turkey to OIC countries. Interestingly, Turkish foreign aid is more inclined to least developing countries, the volume of export to these countries was very negiligible before they did not Turkish foreign aid. However, statistics show that volume of export to OIC least developed countries has been increasing as the rate of Turkish official development assistance to these countries increased. Finally, we are recommending future researchers to examine whether there is causal relationship Turkish official development assistance or foreign aid as a whole and volume of export to Turkish aid recipient countries.

\section{References}

Ertuğrul, A., \& Selçuk, F. (2001). A Brief Account of the Turkish Economy, 1980-2000. Russian \& East European Finance and Trade, 37(6), 6-30.

Macovei, M. (2009). Growth and economic crises in Turkey: leaving behind a turbulent past? Brussels: European Commission Directorate-General for Economic and Financial Affairs.

Nguyen, D. P., \& Vo, V. X. (2017). Determinants of bilateral trade: evidence from ASEAN+ 3. AsianPacific Economic Literature, 115-116.

Abidin, I. Z. (2018). MALAYSIA-GCC BILATERAL TRADE , MACROECONOMIC INDICATORS AND ISLAMIC FINANCE LINKAGES:A GRAVITY MODEL APPROACH. Academy of Accounting and Financial Studies Journal, 22(01), 1-2. 
Abidin, I. Z., \& Haseeb, M. (2018). MALAYSIA-GCC BILATERAL TRADE, MACROECONOMIC INDICATORS AND ISLAMIC FINANCE LINKAGES: A GRAVITY MODEL APPROACH. Academy of Accounting and Financial Studies Journal, 22(1), 1-2.

Abidin, I. Z., Abu Bakarb, N. A., \& Sahlan, R. (2013). The Determinants of Exports between Malaysia and the OIC Member countries: Gravity Model Approach. Procedia Economics and Finance, 12-19(5), 17-18.

Al-tarash, H., \& Yousef, T. (2000). Intra-Arab trade: is it too little? Washington: International Monetary Fund.

Bendjilali, B. (2000). An Intra-trade Eonometric model for OIC member countries: A crorss country Analysis. Jidah: Islamic development Bank.

Bilgin, M. H., Gozgor, G., \& Demir, E. (2017). The determinants of Turkey's exports to Islamic countries: The impact of political risks. The Journal of International Trade \& Economic, 27(5), 487.

Boughanmi, D. (2008). The Trade Potential of the Arab Gulf Cooperation Countries (GCC): A Gravity Model Approach. Journal of Economic Integration, 23(1), 43-44.

Ghani, G. M. (2011). The Impact of Trade Liberalisation on the Economic Performance of OIC Member Countries. Journal of Economic Cooperation and Development, 32(01), 3-4.

Gundogdu, A. S. (2009). Determinants of Intra-OIC Trade: Policy or Exchange rate. Journal of Economic Cooperation and Development, 2-3.

Khalifah, N. A. (1993). The Structure of Intra-Muslim Countries Trade. Jurnal Ekonomi Malaysia, 57-84(27), 58-59.

Sayari, S. (2000). Turkish Foreign Policy in the Post-Cold War Era: The Challenges of MultiRegionalism. Journal of International Affairs, 54(1), 169-182.

Ucal, M. Ş., \& Alıcı, A. A. (2003). Foreign direct investment, exports and output growth of Turkey: Causality analysis. European Trade Study Group (ETSG) fifth annual conference, , 11-13.

Yogatama, A. R., \& Hastiadi, F. F. (2015). The Role of Democracy and Governance in the Enhancement of Indonesian. Working Paper in Economics and Busines, 4, 1-2.

Zarzoso, I. M. (2003). Gravity Model: An Application to Trade between Regional Blocs. Atlantic Economic Journal, 176. 